\title{
Seasonal physico-chemical attributes of the river Buriganga, Turag and Balu, Bangladesh
}

\author{
Mizanur Rahman*, M. Mahfuzur Rahman, Sirajul Hoque ${ }^{1}$ and Hassan Mahmud ${ }^{2}$ \\ Plant Ecology and Environment Laboratory, Department of Botany, \\ Jahangirnagar University, Savar, Dhaka-1342, Bangladesh
}

\begin{abstract}
Seasonal physico-chemical attributes $\left(\mathrm{p}^{\mathrm{H}}, \mathrm{EC}\right.$, TSS, TDS, DO, BOD, COD, $\mathrm{Cl}, \mathrm{HCO}_{3}, \mathrm{NO}_{3}-\mathrm{N}$, $\mathrm{NH}_{4}-\mathrm{N}, \mathrm{Na}, \mathrm{K}, \mathrm{Ca}, \mathrm{Mg}, \mathrm{Fe}, \mathrm{Zn}, \mathrm{Cu}, \mathrm{Ni}, \mathrm{Al}, \mathrm{Pb}, \mathrm{Cd}, \mathrm{Cr}$, and $\mathrm{Hg}$ ) of the river Buriganga, Turag and Balu have been studied to determine the pollution level of these rivers. It was revealed that most of the attributes exceeded the standard values set by GOB. Specially the parameters measured for the river Buriganga and Turag were in danger level. The level of pollution was much higher in winter and summer seasons compared to monsoon.
\end{abstract}

Key words: Physico-chemical attributes, Buriganga, Turag, Balu, Pollution.

\section{INTRODUCTION}

Dhaka is one of the most densely populated cities in the world (WHO, 1992). There are number of rivers around the city such as the Buriganga, Turag, Balu, Bongshi, Karnatali etc. (GOB, 1997), but most of them are biologically dead or about to die (Karn \& Harada, 2001; Bangladesh River System, 2004). All of Dhaka's sewage and industrial wastes are flushed directly or indirectly into these rivers (Ahmed \& Reazuddin, 2000; Subramanian, 2004). The major polluting industries are tanneries, textiles, dying, pulp and paper and steel re-rolling mills which are located beside the Buriganga, Turag and Balu river. (Ahmed, 1985). These industries are discharging heavy metals like $\mathrm{Fe}, \mathrm{Zn}, \mathrm{Pb}, \mathrm{Co}, \mathrm{Mo}$, $\mathrm{Cd}, \mathrm{Ni}, \mathrm{Cr}, \mathrm{Hg}$, As, (Ahmed \& Reazuddin, 2000) and some acids and solvents like $\mathrm{H}_{2} \mathrm{SO}_{4}, \mathrm{HCl}$, carboxylic acids, phenol, organic acids, triphenyle methane etc. (Rahman,1997; Ahmed, 2007) and some dying materials like Paranitraniline red, Mauveine, Heptamethine, Fuchsine, Rhodamine, Quinoline, Solvent red 164, Pararosaniline etc. (Jones, 1952; OSA, 1943). In Dhaka, the tannery industries of Hazaribag are discharging their wastewater into the Buriganga river through three outfalls (Kawser et al., 2011). Some other industries located in the Fatullah (Narayanganj) industrial area (mainly textiles and steel re-rolling mills) discharged their effluents partly via the floodplain of the Buriganga river. Tongi industrial area (mainly textiles and steel re-rolling mills) drains out its wastewater through a canal to the Turag river and the southern part of the Turag is connected with the Buriganga. Effluents of the Tejgaon

\footnotetext{
${ }^{1}$ Department of Soil Water and Environment, University of Dhaka, Dhaka-1000, Bangladesh

${ }^{2}$ Department of Environmental Science and Management, North South University, Dhaka, Bangladesh

* Corresponding author: mizanju_botany@yahoo.com
} 
industrial area (textile, chemical, paper \& steel re-rolling mill) are being discharged as diluted forms via drains and lowland into the rivers Buriganga, Turag and Balu (Rahman et al., 2001).

A healthy reverine ecosystem requires some standard water quality parameters like $\mathrm{p}^{\mathrm{H}}-7$, EC 300ms $/ \mathrm{cm}$, TSS-1, TDS-5, DO- 4, BOD-6, COD-6, Cl- 13, NO $\mathrm{N}_{3}-\mathrm{N}-6, \mathrm{NH}_{4}-\mathrm{N}-1$, Na- 6.5, K- 1.2,Ca-36, Mg-8, Zn-1, Cu-0.5, Ni-0.001, Al-0.02, Pb-0.010, Cd-0.005, Cr$0.001, \mathrm{Hg}-0.005$ in $\mathrm{mg} / \mathrm{l}$. (Ayres \& Westcot, 1985).

According to GECA (1995) the above mentioned rivers have lost their ecological health. The ecological disaster has imposed an economical vulnerability to Bangladesh. But still a comparative status of these three rivers have not been studied. It is necessary to obtain sufficient scientific data on these rivers to manage the river ecosystems. To address this national need, the present research has been designed to investigate the physico-chemical attributes of the river Buriganga, Turag and Balu around the capital Dhaka.

\section{MATERIALS AND METHODS}

Sampling site selection : Samples were collected from 4 locations of each river based on the industrial density at their banks, such as for the Buriganga the locations were Sadarghat, Jhauchor, Bosilla and Sluicegate; for the Turag the points were Ashiulia, Tongi, Pagar and Ujhampur; and for the Balu the locations were Ulukhola, Kanchon, Isapura and Demra as shown in Figure 1.

Sampling seasons: Water samples were collected in three distinct seasons: Summer (March-May), Monsoon (June-August) and winter (Dec-Feb) in the year of 2011 to 2012.

Sampling layers: Water samples were collected from three different layers of each location as Upper layer (surface), Middle layer (3 meter depth) and Lower layer (6 meter depth) (as per Montgomery \& Hart, 1974)

Selection of parameters: 24 vital parameters were selected for water quality analysis under two categories- a) Physical parameters- $\mathrm{pH}$, TSS and TDS (APHA, 1971) b) Chemical parameters- EC, DO, BOD, COD, Cl, $\mathrm{HCO}_{3}, \mathrm{HNO}_{3}-\mathrm{N}, \mathrm{NH} 4-\mathrm{N}, \mathrm{Na}, \mathrm{K}$, $\mathrm{Ca}, \mathrm{Mg}, \mathrm{Fe}, \mathrm{Zn}, \mathrm{Cu}, \mathrm{Ni}, \mathrm{Al}, \mathrm{Pb}, \mathrm{Cd}, \mathrm{Cr}$ and $\mathrm{Hg}$ (APHA, 1971).

Sample collection and preservation: All the water samples were collected by water sampler (Model: UWITEC, A-3510). Samples were preserved in two methods, one for normal for non metallic analysis and other for metallic analysis which was preserved by adding very few drops of $\mathrm{HNO}_{3}$ as reported by (Chapman, 1996). 


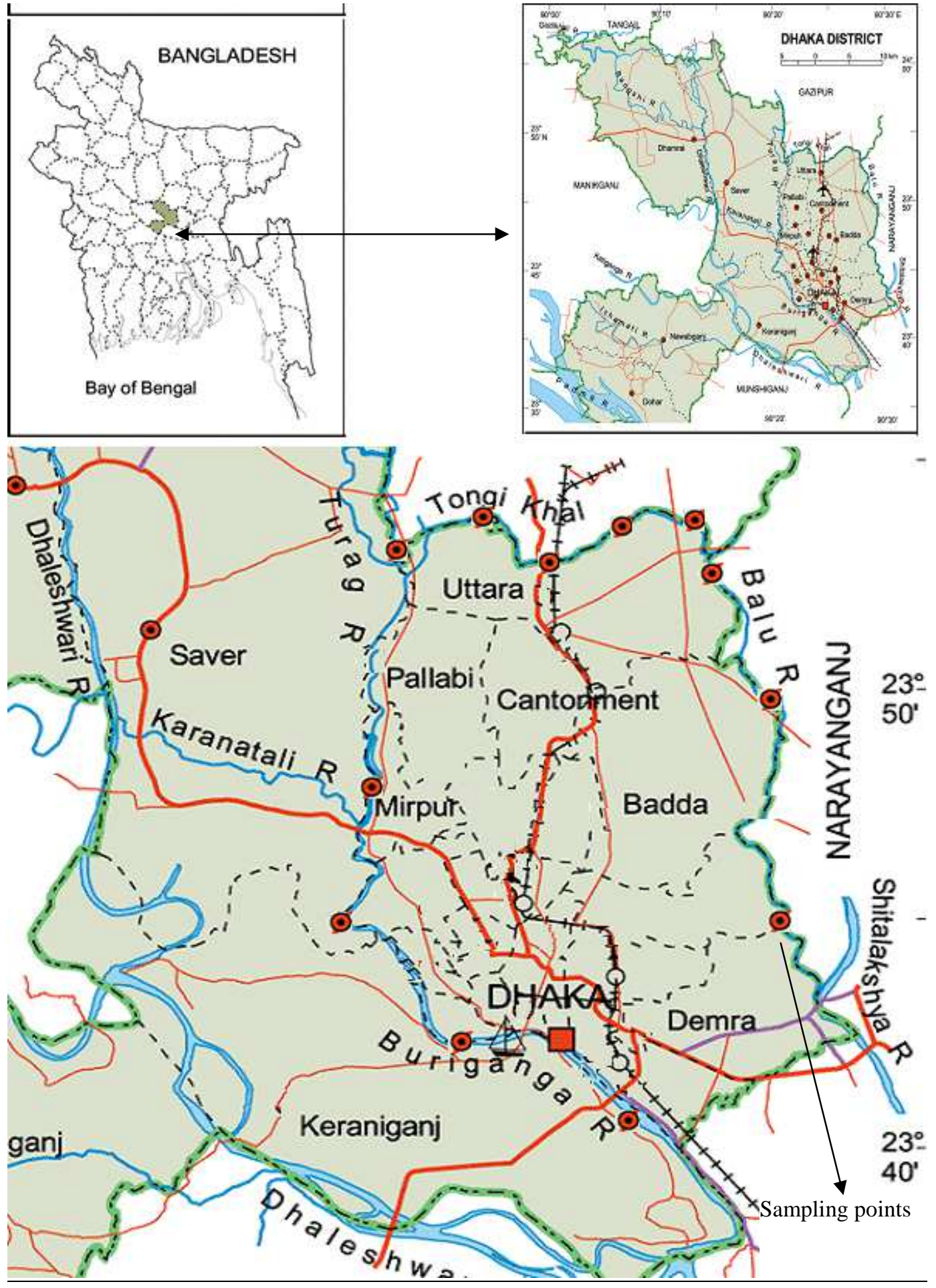

Fig. 1. Map showing the study sites. (All round-red marks are the sampling points) 
Sample analysis: Proper sampling procedure was followed carefully to inhibit the intrusion of any foreign particles that may affect the results. Some parameters like Temperature, $\mathrm{pH}$ and DO were measured instantly at the spot by Hanna instrument H19033 (Gupta, 2000). Rest of the samples were analyzed in laboratory. TSS and TDS were determined by Filtration process (Lenore et al., 1998). BOD, COD and $\mathrm{HCO}_{3}$ were determined by titrimetric method (Lenore et al., 1998); Cl by Mohr volumetric method (Chapman, 1996); $\mathrm{HNO}_{3}-\mathrm{N}$ and $\mathrm{NH} 4-\mathrm{N}$ by Micro-Kjeldahl distillation method (Gupta, 2000); Na and $\mathrm{K}$ by Flame-photometric method (Lenore et al., 1998); Ca and Mg by EDTA titrimetric method (Lenore et al., 1998); $\mathrm{Fe}, \mathrm{Zn}, \mathrm{Cu}, \mathrm{Ni}, \mathrm{Al}, \mathrm{Pb}, \mathrm{Cd}, \mathrm{Cr}$ and $\mathrm{Hg}$ by Atomic Absorption Spectrophotometric (AAS) method (Glanje, 1996).

\section{RESULTS AND DISCUSSION}

Buriganga : Physico-chemical parameters have been presented in Table 1. Water of this river was highly acidic (average $\mathrm{pH}-4.05$ ) in winter. It may be due to low water volume, high amount of dying and tannery disposal etc. But in summer the $\mathrm{pH}$ was 6.05 and in monsoon it was 7.16 which did not deviate much from the standard value. This finding is different from the findings of Kamrul et al. (2008) and Kamal et al. (1999). The EC value was $753 \mathrm{~ms} / \mathrm{cm}$ in winter whereas in summer it was $678.50 \mathrm{~ms} / \mathrm{cm}$ and $552 \mathrm{~ms} / \mathrm{cm}$ in monsoon. In winter the DO was very low $(2.3 \mathrm{mg} / \mathrm{l})$. But in winter TSS, TDS, BOD and COD values were $158.25,1015.17,68.36$ and $139.21 \mathrm{mg} / \mathrm{l}$ respectively which were much higher than the standard values, but in summer the values were $3.45,49.35,126.39 \mathrm{mg} / \mathrm{l}$ respectively and in monsoon which were $4.69,35.95$ and $90.88 \mathrm{mg} / \mathrm{l}$ respectively (Table 1). Values of these three parameters were more or less similar with the findings reported by Kamrul et al. (2008); Begum et al. (2010), Masuduzzaman \& Rafiq (2006) who worked on water quality status of the surrounding rivers of Dhaka. The concentration of $\mathrm{Cl}$ (82.49), $\mathrm{NO}_{3}-\mathrm{N}(21.28)$, and $\mathrm{NH}_{4}-\mathrm{N}(9.78) \mathrm{mg} / \mathrm{l}$ were also highest in winter. Although in summer these values were $5-10 \%$ and $10-30 \%$ less than those in winter and in monsoon respectively, however all were beyond the standard values. Kawser et al., (2011) worked on the effect of textile and tannery effluents on the water quality of the river Buriganga, where they found the value of BOD, TDS, TSS, Na, K, Ca, Fe and $\mathrm{Cl}$ were 74.0, 2188, $899.6,707.7,53.5,46.7,0.135$, and $78.81 \mathrm{mg} / \mathrm{l}$ respectively during summer season. The results of the present study were more or less similar to the BTMA report of 2007. The $\mathrm{HCO}_{3}$ value was $113.13 \mathrm{mg} / \mathrm{l}$ in summer and $80.24 \mathrm{mg} / \mathrm{l}$ in monsoon but in winter the value was zero because $\mathrm{HCO}_{3}$ does not exist if the $\mathrm{pH}$ is below 4.23 (Trivedi \& Gurdeep, 1997). In winter the concentrations of $\mathrm{Na}, \mathrm{K}, \mathrm{Ca}$, and $\mathrm{Mg}$ were 58.10, 7.14, 16.01 and $19.06 \mathrm{mg} / \mathrm{l}$, respectively (Table 1). It was found that all recorded heavy metal concentrations in water crossed the safety limit in summer, monsoon and winter. Among these the $\mathrm{Fe}, \mathrm{Zn}, \mathrm{Cu}, \mathrm{Ni}, \mathrm{Al}, \mathrm{Pb}, \mathrm{Cd}, \mathrm{Cr}$ and $\mathrm{Hg}$ concentrations were highest in winter, which were $1.79,0.85,0.21,0.04,1.42,0.11,0.05,0.04$ and $0.05 \mathrm{mg} / \mathrm{l}$, respectively. These results indicate that the river Buriganga is highly polluted. Rahman et al. (2007) reported 20-70 ppm $\mathrm{Pb}$ and 0.03-0.43 ppm of $\mathrm{Cd}$ in textile effluent discharging zone of Turag river during summer. In summer the values were slightly lower but in monsoon it was about half of the winter value although all the values were much higher than the standard values (Table 1). 
Table 1. Seasonal physico-chemical properties (average value) of the river Buriganga, Turag and Balu in different seasons

\begin{tabular}{|c|c|c|c|c|c|c|c|c|c|c|c|}
\hline \multirow{2}{*}{\multicolumn{2}{|c|}{$\begin{array}{l}\text { Parameter } \\
\text { and units }\end{array}$}} & \multicolumn{3}{|c|}{ Buriganga } & \multicolumn{3}{|c|}{ Turag } & \multicolumn{3}{|c|}{ Balu } & \multirow{2}{*}{$\begin{array}{l}\text { Standard } \\
\text { value }\end{array}$} \\
\hline & & Summer & Monsoon & Winter & Summer & Monsoon & Winter & Summer & Monsoon & Winter & \\
\hline $\mathrm{pH}$ & & 6.05 & 7.16 & 4.05 & 7.20 & 7.28 & 5.39 & 6.70 & 7.16 & 6.71 & 7.0 \\
\hline EC & $\begin{array}{l}\mathrm{ms} / \\
\mathrm{sec}\end{array}$ & 678.5 & 552 & 753.25 & 488.75 & 344.5 & 477 & 332.2 & 311.5 & 330.2 & 300 \\
\hline TSS & $\mathrm{mg} / \mathrm{l}$ & 129 & 84.75 & 158.25 & 83.75 & 69.00 & 103.7 & 35.08 & 22.8 & 41.08 & $0-1$ \\
\hline TDS & $"$ & 424.9 & 168.03 & 1015.1 & 104.64 & 116.42 & 197.1 & 40.84 & 22.36 & 50.35 & $5-10$ \\
\hline DO & $"$ & 3.45 & 4.69 & 2.39 & 4.32 & 5.22 & 3.46 & 5.187 & 5.72 & 4.49 & $4-6$ \\
\hline BOD & $"$ & 49.35 & 35.95 & 68.36 & 47.09 & 40.34 & 55.91 & 25.13 & 17.60 & 28.99 & $6-10$ \\
\hline COD & $"$ & 126.3 & 90.88 & 139.21 & 127.05 & 102.59 & 185.7 & 24.10 & 16.15 & 26.90 & $6-10$ \\
\hline $\mathrm{Cl}$ & $"$ & 60.56 & 47.34 & 82.49 & 70.73 & 52.05 & 70.93 & 23.89 & 14.26 & 27.54 & 13 \\
\hline $\mathrm{HCO}_{3}$ & $"$ & 113.1 & 80.24 & Nil & 148.59 & 160.89 & 80.94 & 106.1 & 89.24 & 132.2 & 119 \\
\hline $\mathrm{NO}_{3}-\mathrm{N}$ & $"$ & 12.85 & 9.61 & 21.28 & 18.17 & 12.52 & 31.74 & 11.01 & 8.37 & 19.19 & $6-8$ \\
\hline $\mathrm{NH}_{4}-\mathrm{N}$ & $"$ & 6.44 & 4.66 & 9.78 & 15.58 & 12.17 & 16.57 & 9.61 & 7.48 & 9.96 & $1-5$ \\
\hline $\mathrm{Na}$ & $"$ & 16.81 & 8.37 & 58.10 & 19.40 & 16.66 & 15.96 & 9.59 & 7.35 & 9.97 & 6.5 \\
\hline K & $"$ & 5.38 & 3.3 & 7.14 & 3.57 & 3.64 & 4.44 & 2.86 & 1.90 & 3.22 & 1.2 \\
\hline $\mathrm{Ca}$ & $"$ & 12.02 & 7.06 & 16.01 & 17.88 & 13.29 & 14.38 & 23.26 & 15.44 & 22.89 & 36 \\
\hline $\mathrm{Mg}$ & $"$ & 16.79 & 9.01 & 19.06 & 12.59 & 10.18 & 15.85 & 10.70 & 8.93 & 11.95 & 8.00 \\
\hline $\mathrm{Fe}$ & $"$ & 1.34 & 0.74 & 1.79 & 3.05 & 2.2 & 2.54 & 1.38 & 0.84 & 1.36 & $0.02-1.0$ \\
\hline $\mathrm{Zn}$ & $"$ & 1.043 & 0.337 & 0.858 & 0.462 & 0.322 & 0.55 & 1.055 & 0.642 & 1.215 & 1.0 \\
\hline $\mathrm{Cu}$ & $"$ & 0.084 & 0.036 & 0.219 & 0.320 & 0.141 & 1.349 & 0.014 & 0.007 & 0.018 & $0.50-1.0$ \\
\hline $\mathrm{Ni}$ & $"$ & 0.036 & 0.017 & 0.047 & 0.020 & 0.016 & 0.022 & 0.009 & 0.005 & 0.014 & $0.001-0.100$ \\
\hline $\mathrm{Al}$ & $"$ & 1.17 & 0.81 & 1.42 & 2.67 & 1.80 & 3.68 & 1.27 & 0.87 & 1.38 & $0.2-0.5$ \\
\hline $\mathrm{Pb}$ & $"$ & 0.075 & 0.052 & 0.111 & 0.065 & 0.033 & 0.080 & 0.031 & 0.014 & 0.034 & 0.010 \\
\hline $\mathrm{Cd}$ & $"$ & 0.033 & 0.010 & 0.052 & 0.010 & 0.007 & 0.016 & 0.009 & 0.007 & 0.013 & 0.005 \\
\hline $\mathrm{Cr}$ & $"$ & 0.306 & 0.08 & 0.468 & 0.073 & 0.062 & 0.153 & 0.025 & 0.013 & 0.035 & 0.001 \\
\hline $\mathrm{Hg}$ & $"$ & 0.017 & 0.010 & 0.050 & 0.04 & 0.032 & 0.108 & 0.014 & 0.008 & 0.285 & 0.005 \\
\hline
\end{tabular}


Turag: This river is also highly polluted like Buriganga and most of the pollutant concentrations were higher in winter than those of summer and monsoon. In winter the average $\mathrm{pH}$ was 5.39 near by the industrial area, whereas in summer it was 7.20 and 7.28 in monsoon (Table 1 ). The DO was only $3.49 \mathrm{mg} / 1$ and the other values were very high such as EC, TSS, TDS, BOD, COD, Cl, $\mathrm{HCO}_{3}, \mathrm{NO}_{3}-\mathrm{N}, \mathrm{NH}_{4}-\mathrm{N}$ were $477 \mathrm{~ms} / \mathrm{cm}, 103.75$ $\mathrm{mg} / \mathrm{l}, 197.12 \mathrm{mg} / \mathrm{l}, 55.91 \mathrm{mg} / \mathrm{l}, 185.78 \mathrm{mg} / \mathrm{l}, 70.93 \mathrm{mg} / \mathrm{l}, 80.94 \mathrm{mg} / \mathrm{l}, 31.74 \mathrm{mg} / \mathrm{l}, 16.57$ $\mathrm{mg} / \mathrm{l}$ in winter, respectively (Table 1). In summer the values were $5-10 \%$ less than winter and $10-30 \%$ less in monsoon but all exceeded the standard limits. The ionic concentration like Na-15.96, mg/l, K-4.44 mg/l, Ca-14.38 mg/l, and Mg-15.85 mg/l were in winter (Table 1). The heavy metals were present highest in winter such as Fe-2.54 mg/l, Zn-0.55 $\mathrm{mg} / \mathrm{l}, \mathrm{Cu}-1.34 \mathrm{mg} / \mathrm{l}, \mathrm{Ni}-0.02 \mathrm{mg} / \mathrm{l}, \mathrm{Al}-3.68 \mathrm{mg} / \mathrm{l}, \mathrm{Pb}-0.08 \mathrm{mg} / \mathrm{l}, \mathrm{Cd}-0.01 \mathrm{mg} / \mathrm{l}, \mathrm{Cr}-0.15$ $\mathrm{mg} / \mathrm{l}$ and $\mathrm{Hg} 0.10 \mathrm{mg} / \mathrm{l}$ (Table 1.). In monsoon the values were comparatively low due to high tide and dilution effect. Roy et al. (2010) reported $0.59 \mathrm{mg} / \mathrm{l} \mathrm{Zn}, 0.127 \mathrm{mg} / \mathrm{l} \mathrm{Cu}, 0.0$ $\mathrm{Pb}$ and $0.0006 \mathrm{mg} / \mathrm{l} \mathrm{Cd}$ in Karanapara canal of Savar.

Balu: Better water quality was recorded in this river compared Buriganga and Turag, such as the $\mathrm{pH}$ was $6.70,7.16$ and 6.71 in summer, monsoon and winter respectively (Table 1). However, the contaminant loading in winter were slightly higher such as EC$330.25 \mathrm{~ms} / \mathrm{sec}$, TSS-41.08 mg/l, TDS-50.35 mg/l, DO-4.49 mg/l, BOD-28.99 mg/l, COD$26.90 \mathrm{mg} / \mathrm{l}$ and $\mathrm{Cl}-27.54 \mathrm{mg} / \mathrm{l}$ comparatively than other two seasons as reported in Table 1. The $\mathrm{HCO}_{3}$ was present in summer, monsoon and winter as $106.18 \mathrm{mg} / \mathrm{l}, 89.24 \mathrm{mg} / \mathrm{l}$ and $132.24 \mathrm{mg} / \mathrm{l}$, respectively (Table.1). The value of $\mathrm{NO}_{3}-\mathrm{N}$ and $\mathrm{NH}_{4}-\mathrm{N}$ was $19.19 \mathrm{mg} / \mathrm{l}$ and $9.96 \mathrm{mg} / \mathrm{l}$ in winter but $8.37 \mathrm{mg} / \mathrm{l}$ and $7.48 \mathrm{mg} / \mathrm{l}$ in monsoon (Table 1). The ionic concentrations were Na-9.97 mg/l, K-3.22 mg/l, Na-9.97 mg/l, and $\mathrm{Mg}-11.95 \mathrm{mg} / \mathrm{l}$ in winter but $7.35 \mathrm{mg} / \mathrm{l}, 1.90 \mathrm{mg} / \mathrm{l}, 15.44 \mathrm{mg} / \mathrm{l}$ and $8.93 \mathrm{mg} / \mathrm{l}$ in monsoon (Table 1). This river also exceeded the standard limit of heavy metal concentrations but not as severe as for the Buriganaga and Turag river in any respect. In winter the concentration of $\mathrm{Fe}, \mathrm{Zn}, \mathrm{Cu}, \mathrm{Ni}$, $\mathrm{Al}, \mathrm{Pb}, \mathrm{Cd}$ and $\mathrm{Cr}$ was $1.36 \mathrm{mg} / \mathrm{l}, 1.21 \mathrm{mg} /, 0.018 \mathrm{mg} / \mathrm{l}, 0.014 \mathrm{mg} / \mathrm{l}, 1.38 \mathrm{mg} / \mathrm{l}, 0.034 \mathrm{mg} / \mathrm{l}$, $0.013 \mathrm{mg} / \mathrm{l}$ and $0.035 \mathrm{mg} / \mathrm{l}$, respectively (Table.1). Delwar \& Hadiuzzaman (2005) conducted a research on water quality of the Shitalakhya and the Balu river. They found that the value of $\mathrm{Al}, \mathrm{Cd}, \mathrm{Cr}, \mathrm{Pb}, \mathrm{Hg}$ and $\mathrm{Zn}$ was 2.95, 0.006, 0.028, 0.074, 0.0032, and $0.246 \mathrm{mg} / \mathrm{l}$ respectively in the Shitalakhya whereas in the Balu river the values were 2.16, $0.006,0.022,0.0,0.0010$ and $1.12 \mathrm{mg} / \mathrm{l}$ respectively. It is assumed that the pollution level has been rapidly increased after 2005 and reached to this severe level in 2012. It was found that the $\mathrm{Hg}$ concentration was very high in winter than other two seasons and than other two rivers, which was $0.285 \mathrm{mg} / \mathrm{l}$ and very higher than the standard value $0.005 \mathrm{mg} / 1$ (Table 1). The most probable reason might be that huge area near the river side was under Boro cultivation and the pesticide used for Boro cultivation might contain large amount of $\mathrm{Hg}$ which would come down to the river in that season.

\section{REFERENCES}

APHA. 1971. Standard Methods for the Examination of Water and Waste Public Health Association, NewYork, USA.

Water. American 
Ahmed, M. F. 1985. Waste disposal and degradation of water quality in and around Dhaka city. Proc. SAARC Seminar on Protecting the Environment, Dhaka.

Ahmed, T. 2007. Characterization of textile effluent from selected industries in DEPZ and their treatment by adsorption- filtration process. M. Sc. Thesis, pp 1-132, Department of Environmental Sciences, Jahangirnagar University, Saver, Dhaka.

Ahmed, A.U. and Reazuddin. 2000. Industrial Pollution of Water Systems in Bangladesh, University Press Limited, Dhaka, Bangladesh, pp 175-178.

Ayres, R. S. and Westcot, D. W. 1985. Water Quality for Agriculture. FAO Irrigation and Drainage Paper No. 29. Food and Agriculture Organization of the United Nations, Rome, pp. 1-117.

Bangladesh River Systems. 2004. U.S. Library of Congress. (Available: http:Iwww.river system Bangladesh - River Systems.htm), pp 42.

BTMA, Bangladesh Textile Mills Association Annual report (2007), pp 14, 35.

Begum, D. A. and Ahmmed, K. M. T. 2010. Proc. of International Conference on Environmental Aspects of Bangladesh (ICEAB10), Japan, Sept. 2010, pp 175-177.

Chapman, D. [Ed.]. 1996. Water Quality Assessments. A Guide to the Use of Biota, Sediments and Water in Environmental Monitoring. 2nd edition. Chapman \& Hall, London.

Delwar, R. M. and Hadiuzzaman . M. 2005. M. Sc.Thesis. BUET. Pollution Status and Trends in Water Quality of the Shitalakhya and Balu Rivers, pp 71-73.

Glanze. 1996. Heavy metal toxicity. International Occupational Safety and Health Information Centre.

GOB. 1997. Statistical year book of Bangladesh, Bangladesh Bureau of Statistics, Dhaka, Bangladesh.

GECA, Guide to the Environmental Conservation Act. (1995) and Rules (1997). Bangladesh centre for advanced studies, pp 204-222.

Gupta, P. K. 2000. Methods in Environmental Analysis: Water, Soil and Air. Agrobios, Jodhpur, India, pp. 5-76.

Jones, H. 1952.The Science of Color. Thomas Y. Crowell Co., New York, N.Y, pp 11-13.

Kamal, M.M., Malmgren-Hansen, A. and Badruzzaman, A.B.M. 1999. Assesment of pollution of river Buriganga , using a water quality model, water science technology, vol. 40(2), pp. 129-136.

Kamrul, H.M. Kyehyun, K. and Hossein, S.Z. 2008. Water Quality and Risk Assessment in Peripheral Rivers of Dhaka City, Bangladesh pp 5-7.

Karn, S.K. and Harada, H. 2001.Surface water pollution in three urban territories of Nepal, India, and Bangladesh. Environ Manage 28(4): pp 483-496.

Kawser, M. A., Monika, D., and Islam, M. 2011, Physico-chemical Properties of Tannery and Textile Effluents and Surface Water of River Buriganga, Bangladesh, World Applied Science Journal, 2011, 12 (2): pp 152-159.

Lenore, S. and Clesceri, WEF., Arnold, C. E., Greenberg, APHA, Andrew D. Eaton, AWWA. 1998. Standard Methods for the Examination of Water and Wastewaters, 20th Edition. American Public Health Association, Washington, DC, pp 23-24.

Masuduzzaman, M.H. and Rafiq. 2006. Water Quality Assesment of Four Rivers Surrounding Dhaka city, B.Sc. Engineering Thesis, BUET, November 2006, pp 71-76.

Montgomery, H.A.C. and Hart, I.C. 1974. The design of sampling programmes for rivers and effluents. Wat. Pollut. Control,73 : pp 77-101.

Mahabubur, M.R., Haoliang. L., Chongling, Y. and Hoque, S. 2007. Academic Internet Journal Open, 21: pp 3-5.

OSA, Optical Society of America. 1943. Committee Report. The concept of color. J. Opt. Soc. Amer. 33: pp 544. 
Rahman, A. 1997. Characteristics of major industrial liquid pollutants in Bangladesh, M.Sc Engg. Project report, Department of Civil Engineering, BUET, Dhaka, Bangladesh. pp2324

Rahman, M.A., Ali, A. and Farooque, C. 2001. People's report on Bangladesh Environment, The University press limited. pp 153-159.

Roy, R., Fakhruddin, A.N.M., Khatun R., Islam M.S., Ahsan, M.A., and Negerd A. J. M. T. 2010. Bangladesh J. Sci. Ind. Res. 45(1), pp 79-84.

Subramanian, B. 2004. Water quality in South Asia. Asian J. Water Environ. Pollut.1(1-2):pp. 4154.

Trivedi, P.R. and Gurdeep, R. 1997. Water pollution. Akashdeep Publishing House. New Delhi, pp 4-7.

WHO. 1992. Revision of the WHO guidelines for drinking water quality, World Health Organisation, Geneva. Report of the final Task Group Meeting, Geneva, Switzerland 2125 September. 